\title{
Prevalensi periodontitis pada pasien diabetes mellitus (Studi observasional di poliklinik penyakit dalam RSUP Dr. Sardjito)
}

\author{
Rezmelia Sari*, Dahlia Herawati*, Rizky Nurcahyanti**, Pramudita Kusuma Wardani** \\ *Departemen Periodonsia, Fakultas Kedokteran Gigi, Universitas Gadjah Mada, Yogyakarta, Indonesia \\ **Program Studi Ilmu Keperawatan Gigi, Fakultas Kedokteran Gigi, Universitas Gadjah Mada, Yogyakarta, Indonesia \\ *JI Denta No 1, Sekip Utara, Yogyakarta, Indonesia; e-mail: rezmelia_sari@mail.ugm.ac.id
}

Submisi: 26 April 2016; Penerimaan: 26 Juli 2017; Publikasi online: 31 Agustus 2017

\begin{abstract}
ABSTRAK
Diabetes Mellitus (DM) adalah penyakit kronis menahun dengan prevalensi yang semakin meningkat dan menimbulkan komplikasi. Komplikasi yang paling sering terjadi di rongga mulut pasien DM adalah periodontitis yang ditandai dengan kehilangan perlekatan jaringan. Penelitian tentang hubungan DM dengan periodontitis banyak dilakukan namun belum ditemukan data mengenai prevalensi periodontitis pada kelompok DM khususnya di DIY dan Jawa Tengah. RSUP Dr. Sardjito merupakan rumah sakit rujukan DIY dan Jawa Tengah sehingga penelitian ini diharapkan dapat memberi gambaran mengenai tingkat kesehatan jaringan periodontal di masyarakat DIY dan Jawa Tengah. Jenis penelitian ini adalah observasional dengan melibatkan 36 orang pasien DM sesuai kriteria subjek yaitu menderita DM tipe II, kooperatif dan bersedia menandatangani informed consent. Variabel terkendali yaitu usia $40-60$ tahun, kebersihan mulut $(\mathrm{OHI})$ menurut Green and Vermillion dalam kriteria baik, tidak menggunakan antibiotik dan antiinflamasi dalam 3 bulan terakhir dan tidak memiliki riwayat penyakit sistemik lain. Dilakukan pemeriksaan kebersihan mulut dilanjutkan dengan pemeriksaan menggunakan probe WHO untuk menentukan ada tidaknya CAL. Data disajikan secara deskriptif. Hasil penelitian menunjukkan bahwa prevalensi periodontitis pada pasien DM di Poli Klinik Penyakit Dalam RSUP Dr. Sardjito adalah $88,24 \%$ dengan rata-rata jarak $C A L$ adalah $4,6 \mathrm{~mm}$. Kesimpulan penelitian ini adalah prevalensi periodontitis pada pasien DM tinggi walaupun status kebersihan mulut tergolong dalam kriteria baik.
\end{abstract}

Kata kunci: diabetes mellitus; kehilangan perlekatan; periodontitis; prevalensi

\begin{abstract}
Prevalence of periodontal diseases in patients with diabetes mellitus (An observational study at internal medicine polyclinic in Dr. Sardjito General Hospital). Diabetes Mellitus (DM) is a chronic disease with an increasing prevalence and causes complications. The most frequent complication found in the oral cavity of patients with diabetes mellitus is periodontal diseases is characterized by the loss of tissue attachment. There have been numerous studies on the association of DM with periodontal diseases but there has not been any data on the prevalence of periodontal diseases in diabetic group, especially in Yogyakarta and Central Java. Dr. Sardjito General Hospital is a referral hospital in DIY and Central Java, so this study is expected to provide a picture regarding the level of periodontal tissue health among people in Yogyakarta and Central Java. This research was an observational study, involving 36 patients with DM according to criteria of the subjects: suffering from type 2 diabetes, being cooperative and willing to sign an informed consent. The controlled variables: being 40-60 years of age, having good oral hygiene $(\mathrm{OHI})$ according to Green and Vermillion, taking neither antibiotics nor anti-inflammatory drugs in the last 3 months, not having a history of other systemic diseases. Oral hygiene exams were carried out, followed by examination using probe WHO to determine if there is CAL. The data were presented descriptively. The results showed that the prevalence of periodontal diseases in patients with DM at Internal Medicine Polyclinic in Dr. Sardjito General Hospital is $88.24 \%$ with a mean of CAL distance of $4.6 \mathrm{~mm}$. The conclusion of this study is that the prevalence of periodontal diseases in patients with $D M$ is high although the oral hygiene status is good.
\end{abstract}

Keywords: diabetes mellitus; loss of attachment; periodontal diseases; prevalence

\section{PENDAHULUAN}

Diabetes mellitus (DM) merupakan penyakit kronis menahun dengan prevalensi yang semakin meningkat di populasi. Penyakit ini terjadi akibat gangguan metabolisme sehingga tubuh tidak dapat mengontrol kadar gula dalam darah. Menurut survei yang dilakukan oleh $\mathrm{WHO}$, Indonesia menempati urutan ke-4 dengan jumlah penderita diabetes terbesar setelah India, Cina dan Amerika Serikat. Tahun 2030, Indonesia diperkirakan akan memiliki penyandang DM sebanyak 21,3 juta jiwa. ${ }^{1}$ DM tipe 2 merupakan jenis yang paling sering ditemukan 
di praktek dokter gigi, sekitar $90 \%$ dari semua penderita DM di Indonesia. ${ }^{2}$

Respon imun pasien DM mengalami gangguan. Adanya perubahan vaskuler pada membrana basalis yang terjadi pada kondisi hiperglikemi menyebabkan gangguan transpor nutrisi dan migrasi sel imun ke jaringan tubuh, termasuk jaringan periodontal. ${ }^{3}$ Hiperglikemi dapat mempengaruhi migrasi dan aktivitas fagositosis mononuklear dan sel $\mathrm{PMN}^{4}$ sehingga walaupun dipengaruhi oleh bakteri yang sama, periodontitis pada pasien Diabetes mellitus diketahui lebih progresif. Bakteri dan produknya memiliki peran secara tidak langsung merangsang inflamasi sehingga menghasilkan mediator inflamasi seperti prostaglandin E2 (PGE2) atau sitokin meliputi Tumor Necrosis Factor-alpha (TNF- $\alpha$ ) dan Interleukin-1 (IL-1). Mediator ini akan merangsang produksi dan aktivasi enzim yang merusak jaringan ikat gingiva serta produksi osteoklas yang akan meresorpsi tulang. ${ }^{3}$

Diabetes mellitus dapat menimbulkan komplikasi kesehatan, secara umum maupun rongga mulut. Dari sekian banyak komplikasi di rongga mulut, periodontitis merupakan komplikasi yang paling sering terjadi. Periodontitis ditandai dengan terjadinya pocket depth $(P D)$, clinical attachment loss (CAL) dan alveolar bone loss ( $A B L$ ). Penelitian epidemiologi menunjukkan bahwa pada pasien dengan DM, resiko untuk terjadinya attachment loss dan alveolar bone loss tiga kali lebih besar daripada penderita yang tidak mengalami $\mathrm{DM} .^{3}$

Insidensi periodontitis meningkat dan dapat menjadi lebih parah pada pasien yang mengalami DM. ${ }^{5} \mathrm{Hal}$ ini tidak selalu berbanding lurus dengan plak dan kalkulus ${ }^{6}$ karena periodontitis juga dipengaruhi oleh faktor lingkungan antara lain kondisi gigi yang berjejal, metabolik, genetik, dan usia. $^{2}$ Banyak penelitian menunjukkan hubungan timbal balik antara periodontitis dan $\mathrm{DM}^{7}$ dengan membandingkan antara periodontitis pada kelompok DM dan periodontitis pada kelompok Non DM namun belum terdapat data mengenai prevalensi periodontitis pada pasien DM khususnya di DIY dan Jawa Tengah. Prevalensi spesifik pada daerah tertentu diperlukan untuk menggali lebih jauh kecenderungan terjadinya penyakit tersebut sehingga upaya pencegahan dapat lebih tepat sasaran.

RSUP Dr.Sardjito merupakan rumah sakit rujukan di DIY dan Jawa Tengah. Penelitian mengenai prevalensi periodontitis di RS ini khususnya di Poliklinik Penyakit Dalam diharapkan dapat memberi gambaran terhadap kesehatan jaringan periodontal di wilayah DIY dan Jawa Tengah dan dapat digunakan sebagai data awal untuk merancang tindakan pencegahan di populasi.

\section{METODE PENELITIAN}

Jenis penelitian ini adalah penelitian observasional dengan pengumpulan data secara cross-sectional. Penelitian dilakukan di Poliklinik Penyakit Dalam RSUP Dr. Sardjito.

Subjek penelitian adalah pasien rawat jalan yang datang ke poliklinik penyakit dalam RSUP Dr. Sardjito pada Agustus hingga September 2014 dan memenuhi kriteria inklusi yaitu menderita DM, kooperatif dan bersedia menandatangani informed consent. Variabel terkendali yaitu usia 4060 tahun, kebersihan mulut $(\mathrm{OHI})$ menurut Green and Vermillion baik, tidak menggunakan antibiotik dan antiinflamasi dalam 3 bulan terakhir dan tidak memiliki penyakit sistemik lain. Data primer didapat dengan wawancara langsung dan pemeriksaan obyektif $(\mathrm{OHI}$ dan $\mathrm{CAL})$ sedangkan data sekunder didapatkan dari riwayat penyakit dalam rekam medis. Setelah dilakukan penelitian dilakukan pengumpulan data yang kemudian disajikan secara deskriptif.

\section{HASIL PENELITIAN}

Telah dilakukan studi observasional yang berjudul Prevalensi Periodontitis pada Pasien Diabetes Mellitus di Poli Penyakit Dalam RSUP Dr. Sardjito selama 1 bulan. Total pasien yang memenuhi kriteria subjek adalah 69 orang tetapi 33 orang menolak untuk mengikuti penelitian dan dilakukan pemeriksaan. Subjek yang bersedia mengikuti penelitian terdiri dari 15 orang $(41,67 \%)$ laki-laki dan 21 orang $(58,33 \%)$ perempuan. Karakteristik subjek dapat dilihat pada Tabel 1. 
Tabel 1. Karakteristik subjek penelitian

\begin{tabular}{c|c|c|c|c}
\hline & Usia & Tinggi Badan & Berat Badan & $\begin{array}{c}\text { Kadar Gula Darah Puasa (mg/ } \\
\text { dl) }\end{array}$ \\
\hline Mean & & & & 235,758 \\
Standar deviasi & 51,44 & 158,107 & 61,897 & 117,5920 \\
\hline
\end{tabular}

Tabel 2. Lama (durasi) menderita DM

\begin{tabular}{l|l|l}
\hline Lama (durasi) menderita DM & Jumlah $(\mathrm{n})$ & Persentase $(\%)$ \\
\hline Kurang dari 3 tahun & 12 & 33,3 \\
Lebih dari 3 tahun & 24 & 66,7 \\
\hline
\end{tabular}

Tabel 3. Hasil wawancara mengenai keluhan di rongga mulut pasien DM

\begin{tabular}{l|l|l}
\hline Durasi menderita DM & Ada keluhan $(\mathrm{n})$ & Tidak ada keluhan $(\mathrm{n})$ \\
\hline Kurang dari 3 tahun & 8 & 4 \\
Lebih dari 3 tahun & 15 & 9 \\
\hline
\end{tabular}

Tabel 4. Hasil Pemeriksaan kebersihan mulut $(\mathrm{OHI}$ menurut Green and Vermillion)

\begin{tabular}{c|c}
\hline Kriteria OHI & Persentase (\%) \\
\hline Baik & 47,22 \\
Sedang & 47,22 \\
Buruk & 5,56 \\
\hline
\end{tabular}

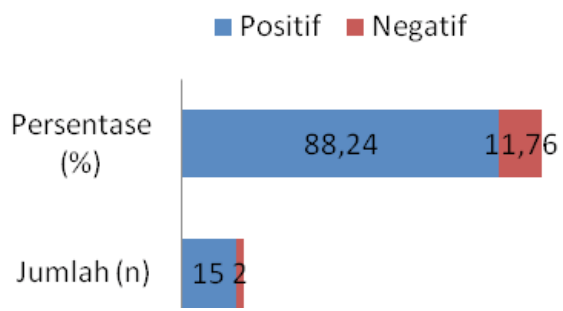

Gambar 1. Hasil pemeriksaan CAL pada pasien DM

Tabel 5. Hasil pengukuran jarak CAL

\begin{tabular}{c|c}
\hline Jumlah gigi CAL positif & 66 gigi \\
\hline Rata-rata & $4,6 \mathrm{~mm}$ \\
\hline
\end{tabular}

Rata-rata usia subjek adalah 51,4 tahun dengan usia termuda adalah 40 tahun dan usia tertua adalah 60 tahun. Kadar gula darah rata-rata (3 bulan terakhir) adalah $235,758 \mathrm{mg} / \mathrm{dl}$ dengan kadar gula tertinggi adalah $500 \mathrm{mg} / \mathrm{dl}$ sedangkan kadar gula terendah adalah $106 \mathrm{mg} / \mathrm{dl}$. Subjek yang bersedia mengikuti penelitian kemudian diwawancarai dan dimohon mengisi kuesioner untuk mendapatkan data mengenai berapa lama (durasi) pasien menderita DM. Informasi ini dapat dilihat pada Tabel 2.
Berdasarkan Tabel 2 diketahui bahwa dari 36 subjek penelitian, 12 orang $(33,3 \%)$ mengalami DM kurang dari 3 tahun sedangkan 24 orang $(66,7 \%)$ lainnya telah menderita DM lebih dari 3 tahun. Selain lama (durasi) menderita DM, juga didapatkan informasi mengenai ada tidaknya keluhan yang dirasakan di rongga mulut. Diketahui bahwa 23 orang pasien DM merasakan keluhan di rongga mulut sedangkan 13 orang lainnya tidak mengeluhkan kondisi rongga mulutnya (Tabel 3 ).

Setelah dilakukan wawancara dan pengisian kuesioner, subjek kemudian diperiksa status kebersihan mulutnya dan dilakukan skoring dengan Oral Hygiene Index menurut Green and Vermillion. Data mengenai Oral Hygiene Index dapat dilihat pada Tabel 4.

Subjek dengan $\mathrm{OHI}$ baik berjumlah 17 orang, $\mathrm{OHI}$ sedang berjumlah 7 orang dan $\mathrm{OHI}$ buruk berjumlah 2 orang. Sesuai dengan kriteria inklusi yaitu $\mathrm{OHI}$ baik, maka jumlah subjek yang memenuhi kriteria inklusi adalah 17 orang $(47,22 \%)$ sedangkan subjek yang dieksklusi karena status $\mathrm{OHI}$ sebanyak 19 orang $(52,78 \%)$.

Subjek yang memenuhi kriteria inklusi (17 orang), dilakukan pemeriksaan lebih lanjut untuk melihat ada tidaknya clinical attachment loss (CAL). Pemeriksaan menggunakan probe WHO dan memperhatikan letak dasar sulkus dan CEJ. Bila dasar sulkus berada diapikal CEJ maka dikategorikan sebagai CAL positif sedangkan bila dasar sulkus tepat pada CEJ dikategorikan sebagai 
CAL negatif. Data hasil pemeriksaan CAL dapat dilihat pada Gambar 1.

Dari Gambar 1 diketahui bahwa 15 orang $(88,24 \%)$ mengalami CAL positif sedangkan CAL negatif hanya 2 orang $(11,76 \%)$. Subjek dengan CAL positif dimasukkan dalam kelompok periodontitis positif dan subjek dengan CAL negatif dimasukkan dalam kelompok periodontitis negatif. Dengan demikian diketahui bahwa prevalensi periodontitis pada pasien DM di Poli Penyakit Dalam RSUP Dr. Sardjito adalah $88,24 \%$.

Subjek yang mengalami periodontitis, dilakukan pengukuran jarak CEJ ke dasar sulkus (CAL) pada setiap gigi. Hasil pengukuran jarak CAL menunjukkan bahwa rata-rata gigi mengalami kehilangan perlekatan sebesar 4,6 $\mathrm{mm}$ (Tabel 5)

\section{PEMBAHASAN}

DM merupakan kumpulan gejala (sindrom metabolik) yang terjadi karena tubuh mengalami gangguan metabolisme dalam mengontrol gula darah. Menurut American Diabetes Association (ADA), seseorang didiagnosa menderita DM berdasarkan pada pemeriksaan gula darah, yaitu bila kadar gula darah puasa $\geq 126 \mathrm{mg} / \mathrm{dL}$ dan atau kadar gula darah sesaat $\geq 200 \mathrm{mg} / \mathrm{dL}$. rata-rata kadar gula darah puasa pasien pada penelitian ini adalah $235,758 \mathrm{mg} / \mathrm{dL}$. Kadar gula darah tertinggi adalah $500 \mathrm{~mm} / \mathrm{dl}$ sedangkan kadar gula darah terendah adalah $106 \mathrm{~mm} / \mathrm{dL}$. Menurut informasi dari pasien DM di Poli Penyakit Dalam RSUP Dr. Sardjito, mereka rutin datang ke poli sebulan sekali untuk melakukan pemeriksaan gula darah.

Dilakukan pemeriksaan pada 36 orang subjek berjenis kelamin laki-laki sebanyak 15 orang $(41,67 \%)$ dan perempuan 21 orang $(58,33 \%)$. Jumlah subjek perempuan pada penelitian ini lebih banyak daripada laki-laki, sama halnya dengan penelitian yang dilakukan di Puskesmas Surabaya (86,67\% penderita adalah perempuan). ${ }^{2}$

Usia rata-rata subjek penderita DM adalah 51,4 tahun dengan usia termuda adalah 40 tahun dan usia tertua adalah 60 tahun. Sebanyak $66,7 \%$ subjek telah menderita DM selama lebih dari 3 tahun dan hanya $33,3 \%$ yang mengalami DM kurang dari 3 tahun. Hal ini disebabkan oleh karena diabetes tipe 2 sering terjadi pada usia dewasa dan kejadian DM berlangsung bertahap sehingga membutuhkan waktu yang lama untuk diidentifikasi dan penegakan diagnosis. Insidensi DM juga dilaporkan meningkat seiring bertambahnya usia. ${ }^{8}$ Usia $\geq 45$ tahun lebih berisiko terkena DM. Hal ini sesuai dengan beberapa studi yang mengatakan bahwa tingkat kerentanan terjangkitnya penyakit DM tipe 2 sejalan dengan bertambahnya umur sehingga penting untuk melakukan pemeriksaan gula darah pada usia 45 tahun.

Usia juga berkaitan dengan kondisi histologis dan klinis pada jaringan mulut. Hal ini terjadi karena pada usia tua terjadi penipisan epitel dan penurunan derajat keratinisasi serta perubahan komponen seluler pada jaringan ikat. Perubahan struktur dan fungsi ini menyebabkan penurunan daya tahan jaringan periodontal sehingga sering menimbulkan keluhan di rongga mulut. ${ }^{9}$

DM dapat menimbulkan komplikasi di rongga mulut sehingga menimbulkan keluhan. Hal ini sesuai dengan hasil penelitian ini yang menunjukkan bahwa pasien DM yang merasakan keluhan di rongga mulut antara lain gigi goyah sehingga tidak nyaman saat mengunyah atau bau mulut (23 orang) lebih banyak daripada pasien DM yang tidak memiliki keluhan apapun (13 orang). Keluhan ini merupakan keluhan yang sering disampaikan pasien yang mengalami periodontitis. Dari sekian banyak komplikasi DM di rongga mulut, periodontitis merupakan komplikasi yang paling sering terjadi. ${ }^{3}$ Komplikasi lain yang sering dirasakan adalah xerostomia namun pada penelitian ini tidak ditemukan.

Periodontitis terjadi karena interaksi banyak faktor, yaitu faktor mikroorganisme dan beberapa faktor resiko lain, yaitu lingkungan, metabolik, genetik dan status kebersihan rongga mulut. $^{5}$ Pemeriksaan kebersihan mulut pada penelitian ini menggunakan skor $\mathrm{OHI}$ menurut Green dan Vermillion. Dari penelitian ini diketahui bahwa $47,22 \%$ pasien DM termasuk dalam $\mathrm{OHI}$ kriteria baik sedangkan $52,78 \%$ pasien termasuk dalam kriteria sedang dan buruk.

Peridontitis pada penyakit sistemik misalnya DM, lebih sering terjadi dan lebih parah, namun 
tidak selalu berhubungan dengan plak dan kalkulus. ${ }^{6} \mathrm{Hal}$ ini sesuai dengan hasil pemeriksaan CAL pada pasien DM di Poli Penyakit Dalam RSUP Dr. Sarjito. Walaupun memiliki status kebersihan mulut yang baik, prevalensi periodontitis tetap tinggi $(88,24 \%)$ dengan rata-rata kehilangan perlekatan sebesar 4,6 $\mathrm{mm}$. Keadaan ini sejalan dengan penelitian epidemiologi yang menunjukkan bahwa pada pasien dengan DM, resiko untuk terjadinya attachment loss dan alveolar bone loss tiga kali lebih besar daripada penderita yang tidak mengalami DM. ${ }^{3}$

Gambar 1 menunjukkan bahwa CAL positif pada $88,24 \%$ subjek. Kondisi ini merupakan salah satu tanda dari terjadinya periodontitis. ${ }^{10}$ Dibandingkan dengan periodontitis pada orang sehat, kerusakan jaringan ikat terjadi lebih parah pada pasien periodontitis dengan DM.

Pasien dengan diabetes beresiko 3 kali lebih tinggi untuk mengalami periodontitis. Apabila periodontitis ini dirawat dengan terapi inisial yaitu scaling dan root planning maka dapat membantu pasien diabetes dalam mengontrol gula darah. ${ }^{11}$ Sebaliknya, apabila periodontitis ini tidak dirawat maka akan mempersulit kontrol glukosa darah dan memperparah periodontitis bahkan menyebabkan hilangnya gigi. Kehilangan gigi dapat menyebabkan menurunnya kualitas hidup pasien diabetes karena gigi berfungsi untuk mencerna makanan pada tahap awal sekaligus estetis. Namun demikian, belum terdapat mekanisme yang jelas mengenai hal ini. Beberapa hipotesa yang muncul adalah a) terjadi perubahan respon immunoinflamatori jaringan terhadap bakteri patogen $b$ ) berkurangnya aspek formatif pada proses metabolisme jaringan ikat c) gangguan penyembuhan luka d) perubahan mikrovaskuler dan e) pembentukan produk akhir glikasi (AGEs). ${ }^{12}$

Hiperglikemi kronik akan meningkatkan aktivitas kolagenase sehingga kolagen akan terurai. Respon imun pasien DM juga dapat berubah. Salah satu kondisi yang terjadi yaitu perubahan vaskuler (mikroangiopati) pada membrana basalis yang menyebabkan gangguan transpor nutrisi dan migrasi sel imun ke jaringan tubuh, termasuk jaringan periodontal. ${ }^{3}$ Hiperglikemi mempengaruhi migrasi dan aktivitas fagositosis mononuklear dan sel $\mathrm{PMN}^{4}$ sehingga walaupun bakteri yang mempengaruhi sama, periodontitis pada pasien DM diketahui lebih progresif. Bakteri dan produknya merangsang inflamasi secara tidak langsung karena menghasilkan mediator inflamasi seperti prostaglandin E2 (PGE2) atau sitokin meliputi Tumor Necrosis Factor-alpha (TNF- $\alpha$ ) dan Interleukin-1 (IL-1) yang akan merangsang produksi dan aktivasi enzim. Produksi dan aktivasi enzim akan merusak jaringan ikat gingiva sedangkan osteoklas yang terlalu aktif juga akan menyebabkan timbulnya resorpsi tulang berlebih. ${ }^{3}$

Advanced glycation end products (AGE) merupakan produk akhir glikasi yang terbentuk dari reaksi non enzimatik glukosa dan peningkatan oksidasi asam lemak. Produk glikasi ini akan berpengaruh pada peningkatan apoptosis osteoblas. Salah satu jalur yang memungkinkan terjadinya hal ini adalah melalui jalur MAP kinase. Diabetes juga mempengaruhi pembentukan tulang karena mengakibatkan penurunan ekspresi faktor transkripsi yang mengartur regulasi differensiasi osteoblas. Penelitian pada model hewan coba tikus, tampak penurunan aktivitas alkalin fosfatase dan pembentukan matriks-mineral. Bila AGEs diaplikasikan ke hewan coba normal akan menyebabkan penurunan kapasitas penyembuhan namun pada hewan coba dengan diabetes (kadar gula yang lebih tinggi) AGEs dapat mempengaruhi remodelling tulang. Disamping itu, reseptor AGEs juga meningkat pada osteoblas pasien DM menyebabkan pasien DM lebih sensitif terhadap AGEs. ${ }^{13}$

Pasien dengan DM tipe II akan mengalami kehilangan perlekatan jaringan periodontal yang lebih banyak daripada pasien tanpa DM. Ratarata kehilangan perlekatan yang terjadi adalah 3-5 $\mathrm{mm}$. Prevalensi kehilangan perlekatan ini akan berbanding lurus dengan durasi DM. ${ }^{14}$

Peridontitis dan DM memiliki hubungan yang kompleks dan dihubungkan dengan mediator inflamasi. Dua dekade terakhir dilakukan penelitian untuk mencari biomarker untuk diabetes dan periodontitis ${ }^{15}$ Salah satu faktor yang tidak dapat di modifikasi dan berhubungan dengan diabetes dan 
periodontitis adalah variasi genetik individu (single nucleotide polymorphism/SNP). Faktor ini akan menentukan respon imun host terhadap stimulus sekaligus menentukan apakah stimulus tersebut akan menyebabkan kerusakan atau tidak. ${ }^{16}$

Beberapa kendala yang ditemukan pada penelitian ini yaitu tingginya penolakan pasien untuk terlibat dalam penelitian (33 orang) karena beberapa alasan antara lain kelelahan karena antrian yang panjang atau khawatir akan tersalip ketika dilakukan pemeriksaan. Kendala lain terkait dengan sulitnya melakukan pemeriksaan kondisi tulang melalui rontgen foto sehingga tidak dapat diketahui pola kerusakan tulang yang terjadi. Hal ini karena jarak antara Poli Penyakit Dalam dan ruang untuk rontgen cukup jauh dan pasien menolak saat ditanyakan kesediaannya.

\section{KESIMPULAN}

Pasien DM di Poli Penyakit Dalam RSUP yang sesuai dengan kriteria subjek lebih banyak berjenis kelamin perempuan daripada laki-laki. Prevalensi periodontitis pada pasien DM cukup tinggi yaitu $88,24 \%$ dengan rata-rata kehilangan perlekatan (CAL) 4,6 mm walaupun status kebersihan mulut (berdasarkan $\mathrm{OHI}$ menurut Green dan Vermillion) tergolong dalam kriteria baik. Diperlukan penelitian lanjutan dengan jumlah subjek yang lebih banyak dan disertai dengan pemeriksaan rontgen untuk mengetahui pola kerusakan tulang yang terjadi pada pasien DM yang mengalami periodontitis.

\section{DAFTAR PUSTAKA}

1. Departemen Kesehatan Republik Indonesia. DM Penyebab Kematian Nomor 6 di Dunia: Kemenkes Tawarkan Solusi CERDIK Melalui Posbindu http://depkes.go.id/index. php?vw=2\&id=2383 diakses 25 Maret 2014

2. Rinto AS, Fidianingsih I. Hubungan antara sikap, perilaku dan partisipasi keluarga terhadap kadar gula darah penderita DM tipe 2 di RS PKU Muhammadiyah Yogyakarta Januari-Juli. Naskah Publikasi Fakultas Kedokteran Universitas Islam Indonesia. Yogyakarta; 2008.
3. Ryan EM, Carnu O, Kamer A. The influence of $\mathrm{dm}$ on the periodontal tissue. J.Am Dent Ass. 2003; 143: $345-405$.

4. Javed F, Ahmed A. Proinflammatory cytokines in the saliva, gingival crevicular fluid and serum of diabetic patients with periodontal disease. J Res Pract Dent. 2013.

5. Preshaw PM, Alba AL, Herrera D, Jepsen S, Konstantinidis A, Makrilakis K, Taylor R. Periodontitis and diabetes: a two-way relationship. Diabetologia. 2012; 55(1): 21 31. doi: 10.1007/s00125-011-2342-y.

6. Mealey B. Diabetes and periodontal disease: position paper. J. Periodontal. 2000; 70: 935 49.

7. Grover HS, Luthra S. Molecular mechanisms involved in the bidirectional relationship between diabetes mellitus and periodontal disease. J Indian Soc of Periodontol. 2013; 17(3): 292 - 301. doi:10.4103/0972$124 X .115642$.

8. Perkeni. Konsensus Pengelolaan dan Pencegahan DM tipe-2 di Indonesia. Perkumpulan Endokrinologi Indonesia Jakarta; 2006. 1 - 10.

9. Tsalikis L. The effect of age on the gingival crevicular fluid composition during experimental gingivitis: a pilot study. The Open Dentistry Journal. 2010; 4: $13-26$.

10. Eshwar S, Ankola AV, Hebbal M. Evaluation of periodontal risk assesment model among adults age 30-60 years attending kle dental college, Belgaum: a hospital-based study. J Indian Soc of Periodontol. 2010; 14(3): 173 - 177.

11. Darre L, Vergnes JN, Gourdy P, Sixou M. Efficacy of periodontal treatment on glycaemic control in diabetic patients: a meta-analysis of interventional studies. Diabetes Metab. 2008; 34: 497 - 506.

12. Mealey BL. Periodontal disease and diabetes. JADA. 2006; 137: 26S - 31S.

13. Wu YY, Xiao E, Graves DT. Diabetes mellitus related bone metabolism and periodontal disease. Int J Oral Sci. 2015; 7(2): 63 - 72. 
Majalah Kedokteran Gigi Indonesia. Agustus 2017; 3(2): 98 - 104 ISSN 2460-0164 (print)

ISSN 2442-2576 (online)

14. Al-Khabbaz AK. Type 2 diabetes mellitus and periodontal severity. Oral Health Prev Dent. 2014; 12(1): 77 - 82.

15. Hanes PJ, Krishna R. Characteristic of inflammation common to both diabetes and periodontitis: are predictive diagnosis and targeted preventive measures possible. EPMA Journal. 2010; 1: 101 - 116.

16. Newman MG, Takei HH, Klokkevold PR, Carranza FA. Carranza's clin periodontology. 12th Ed. Elsevier. Canada; 2013. 